\title{
Antioxidant activity of ethanolic extract of three Selaginella species from Java Island, Indonesia
}

\author{
MIFTAHUDIN ${ }^{1, \boldsymbol{v}}$, RINI SYAHRAYNI HASIBUAN ${ }^{2}$, TATIK CHIKMAWATI ${ }^{1}$ \\ ${ }^{1}$ Department of Biology, Faculty of Mathematics and Science, Institut Pertanian Bogor. J1 Agatis, Kampus IPB Darmaga, Bogor 16680, West Java, \\ Indonesia. Tel./fax.: +62-251-8622833, `email: miftahudin@apps.ipb.ac.id \\ ${ }^{2}$ Madrasah Aliyah Negeri 2 Model Medan. Jl. Willem Iskandar No 7A, Medan 20222, North Sumatra, Indonesia
}

Manuscript received: 1 September 2019. Revision accepted: 25 November 2019.

\begin{abstract}
Miftahudin, Hasibuan RS, Chikmawati T. 2019. Antioxidant activity of ethanolic extract of three Selaginella species from Java Island, Indonesia. Biodiversitas 20: 3715-3722. Three Selaginella species, S. ornata, S. plana, and S. willdenowii, from Java Island, Indonesia, have been known to have antioxidant properties; however, in vivo antioxidant activities of these species have not been reported. This research aimed to evaluate the in vivo antioxidant activity of ethanolic extract of three Selaginella species. The $70 \%$ ethanol extract of three Selaginella species at four different doses was administered to mice one day before being treated with oxidative stress. The liver tissue of mice treated with or without oxidative stress was analyzed their lipid peroxidation by measuring MDA concentration and Superoxide Dismutase (SOD) activities. The results showed that there were variations in antioxidant activity among the three Selaginella species. In general, the dose of $0.3 \mathrm{~g}$ extract $\mathrm{kg}^{-1} \mathrm{BW}$ has been able to reduce lipid peroxidation and increase SOD

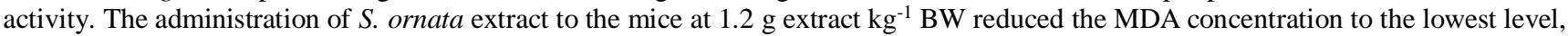
but the same dose of two other Selaginella extracts caused toxic effects in mice. The antioxidant activities of S. ornata and S. plana were better than that of $S$. willdenowii extract, and among those species, S. ornata has the best antioxidant activity.
\end{abstract}

Keywords: Antioxidant, MDA, Selaginella, SOD

\section{INTRODUCTION}

The declining quality of the environment causes humans to be continuously exposed to polluted environments, high ultraviolet radiation, and other free radicals that cause oxidative stress, which subsequently causes premature aging and various degenerative diseases. Consumption of antioxidants is needed to reduce the level of oxidative stress. Antioxidants are compounds that can delay, slow down, or prevent free radicals from causing lipid peroxidation. Antioxidant compounds play an important role in reducing oxidative damage of cells and tissues caused by Reactive Oxygen Species (ROS). Free radicals include superoxide anion radicals, hydroxyl radicals, oxygen singlets, and non-free radical compounds such as hydrogen peroxide (Kumar et al. 2010; Nimse and Pal 2015).

Antioxidants are widely used in the food industry to prevent food deterioration and extend food shelf life (Ghasemzadeh et al. 2012). In recent years, there has been a rapidly growing interest in natural antioxidants since synthetic antioxidants are suspected to increase the risk of human cancer and liver damage (Mavundza et al. 2010). Some medicinal plants have been found to possess antioxidant activity due to the presence of diterpenes, flavonoids, tannins, and phenolic acids (Dawidowicz et al. 2006; Irudayaraj 2010).

Selaginella, the genus of Pterydophyte, is characterized by scale-like leaves (microphylls), mostly growing on organically-rich, moist, well-drained soils in shade or half shade, often near streams, beside trails, and at the edge of clearings in lowland to mid-montane primary and secondary forests (Mukhopadhyay 2001). Selaginella is a potential source of natural antioxidant since it is rich in active biflavonoid compounds, secondary metabolites in the dimer form of flavon and flavanone with 5,7-4'oxygenation pattern (Seigler 1998). Previous studies showed that several species of Selaginella exhibit good antioxidant activities. The extract of $S$. bryopteris contributes favorably to the memory enhancement effect (Garg et al. 2012), possess anti-stress and antioxidant activities that may help relieve stress-induced complications including those caused by heat shock (Sah et al. 2005). The study by Woo et al. (2005) showed that the extract of $S$. tamariscina inhibits the production of oxide nitrate, and the expression of nitrate oxide synthase (iNOS) induced lipopolysaccharides (LPS). Chai and Wong (2012) reported that aqueous extract of Selaginella willdenowii contains phenolic dan flavonoids and showed the free radical scavenging and ferric reducing activities so that $S$. willdenowii was a good source of dietary antioxidant as well as a medicinal herb. Furthermor, Chai and Wong (2012) reported that the antioxidant activity of $S$. willdenowii was correlated to the total phenolic content. Ethanolic extracts of $S$. involvens, $S$. intermedia, $S$. inaequalifolia, and $S$. tenera have been reported to possess antioxidants activity (Sivaraman et al. 2013). Yao et al. (2017) reported that $S$. doederleinii contains eight biflavonoid types which enhanced the antitumor immune response in the mouse lung cancer model. Syaefudin et al. 
(2016) reported that nanoparticle of $S$. doederleinii leaves extract could inhibit A549 cancer cell growth. The extract of $S$. convoluta also showed good antioxidant activities that correlated with the presence of phenolic compounds in its active fractions (de Oliveira Macêdo 2018).

In Indonesia, Selaginella is found on several islands including Sumatera, Java, Lesser Sunda Island, and the Moluccas. Selaginella ornata, S. plana, and S. willdenowii are abundantly found in Java Island. Local people in West Java use those three species of Selaginella as medicinal plants. Extracts of those three species were reported to contain alkaloid, flavonoid, saponin, tannin, and steroid (Chikmawati et al. 2012). The previous study by Chikmawati et al. (2009) showed that the extracts of 3 Selaginella species were able to scavenge radical hydroxyl and inhibit lipid peroxidation in the liver cell of mice. Besides, $S$. plana extract has the best ability to reduce lipid peroxidation (40\%) (Chikmawati et al. 2009). To the best of our knowledge the in vivo antioxidant activity of $S$. ornata, S. plana, and S. willdenowii collected from Java Island has not been reported. The objective of this study was to evaluate the in vivo antioxidant activity of three Selaginella species (S. ornata, S. plana, and S. willdenowii) collected from Java Island in mice.

\section{MATERIALS AND METHODS}

\section{Plant materials and plant extract preparation}

Three species of Selaginella, i.e., S. ornata, S. plana, and $S$. willdenowii, were used in this experiment. Crowns (leaves and stems) of three Selaginella species were cleaned under tap water, drained and dried in an oven at $50^{\circ} \mathrm{C}$ for three days. Dried samples were ground into powder using a grinder. Five grams of Selaginella powder of each species were macerated with $100 \mathrm{~mL}$ of $70 \%$ ethanol at room temperature for $24 \mathrm{~h}$ and stirred with a stirrer bar at $300 \mathrm{rpm}$ for four hours (Gayathri et al. 2005). The filtrate was filtered using Whatman filter paper no. 42 and evaporated using a rotary vacuum evaporator at $60^{\circ} \mathrm{C}$ for 3 to $4 \mathrm{~h}$ at $200 \mathrm{rpm}$. The remaining water was removed by drying the concentrated extract with a freeze dryer to form a paste and stored in a refrigerator at $4^{\circ} \mathrm{C}$.

\section{Experimental animals}

Male DDY (Deutch Danken Yolken) mice, 2.5-3month-old, weighing 21.7-40.8 g were used to evaluate the antioxidant activity of the Selaginella extract. The experimental procedure on animals was carried out following the Experimental Rules of Bogor Agricultural University, Indonesia. The experiment was carried out in Pharmacology Laboratory, Faculty of Veterinary, Bogor Agricultural University, Indonesia with room temperature condition and lighting with 12 hours white light each day.

\section{Acute toxicity}

The toxic effect of extract of three Selaginella species was tested on male DDY mice. A preliminary study of the toxic effect using a dose of $15 \mathrm{~g}$ extract $\mathrm{kg}^{-1} \mathrm{BW}$ (bodyweight). Selaginella extract is administered orally once to mice. Each extract of Selaginella was tested on five mice. Bodyweight and mortality were observed at $24 \mathrm{~h}$ and the seven days after treatment (Harmita and Radji 2008).

Acute toxicity test to determine the $\mathrm{LD}_{50}$ value of three Selaginella extracts was carried out using the Weil method (Weil 1952). Four doses of Selaginella extract (1, 3, 9, dan $27 \mathrm{~g}$ extract $\mathrm{kg}^{-1} \mathrm{BW}$ ) were administered orally to mice. Each experimental unit consisted of four mice. The dosage selection was carried out based on geometric progression (Harmita and Radji 2008) using the following formula:

$$
\begin{aligned}
& \mathrm{Y}_{\mathrm{N}}=\mathrm{Y}_{1} \mathrm{R}^{\mathrm{N}-1} \\
& \text { Where: } \\
& \mathrm{Y}_{\mathrm{N}}: \text { the } \mathrm{N}^{\text {th }} \text { dose } \\
& \mathrm{Y}_{1}: \text { the first dose } \\
& \mathrm{R}: \text { multiplication factor } \\
& \mathrm{N}: \text { dosage series }
\end{aligned}
$$

The toxic effects of the Selaginella extract were evaluated at $24 \mathrm{~h}$ and seven days after treatment (Harmita and Radji 2008) and the median lethal dose (LD $\left.{ }_{50}\right)$ was calculated based on the Weil method (Weil 1952) using the following formula:

$$
\begin{aligned}
& \log \mathrm{m}=\log \mathrm{D}+\mathrm{d}(\mathrm{f}+1) \\
& \text { Where: } \\
& \mathrm{m}: \mathrm{LD}_{50} \text { value } \\
& \mathrm{D}: \text { the smallest dose given } \\
& \mathrm{d}: \log \text { of dose multiplication }(\log \mathrm{R}) \\
& \mathrm{f}: \text { a factor in Weil table }
\end{aligned}
$$

\section{Experimental design for in-vivo antioxidant assay}

The experiment was designed in a Completely Randomized Design with two factors. The first factor was three species of Selaginella ( S. ornata, S. plana and S. willdenowii), and the second factor was the dose of Selaginella extract $\left(0,0.3,0.6\right.$, dan $1.2 \mathrm{~g}$ extract $\left.\mathrm{kg}^{-1} \mathrm{BW}\right)$. Mice were divided into four treatment groups, i.e.: (i) Mice were neither administered with Selaginella extract nor treated with oxidative stress, (ii) Mice were not administered with Selaginella extract but treated with oxidative stress, (iii) Mice were administered with Selaginella extract but not treated with oxidative stress, (iv) Mice were both administered with Selaginella extract and treated with oxidative stress. The Selaginella extracts were administered orally using a syringe (oral sonde). Each experimental unit has consisted of 3 mice.

\section{Selaginella extract application and oxidative stress treatment}

The administration of Selaginella extracts and oxidative stress treatment was conducted based on the method by Gayathri et al. (2005) and Wresdiyati et al. (2007) with a modification. An amount of $0.5 \mathrm{ml}$ Selaginella extract with the appropriate dose of treatment was administered orally to the mice once a day before oxidative stress treatment. Oxidative stress was induced by fasting, but mice have free access to drinking water and the animals subjected to the 
forced swimming activity for five minutes a day for three days. On the fifth day, mice were euthanized with cervical dislocation procedure, and the liver samples were dissected from each mouse, soaked in $0.9 \% \mathrm{NaCl}$ and then stored in a $1.15 \% \mathrm{KCl}$ solution (Okhawa et al. 1979) for further use.

\section{Liver homogenate preparation}

The liver was washed with aquabidest and weighed to make a final concentration of $25 \%$ homogenate in aquabidest (Gayathri et al. 2005). Liver tissue was ground with a mortar and filtered with cheesecloth. The filtrate was either directly used for analysis or stored at $-20^{\circ} \mathrm{C}$ for further use (Hasani et al. 2007).

\section{Lipid peroxidation assay}

The ability of Selaginella extract to inhibit membrane lipid peroxidation was tested using the $\mathrm{Fe}^{2+} /$ ascorbate system (Gayatri et al. 2005). Lipid peroxidation measurement by Thiobarbituric acid (TBA) assay was carried out according to the method by Okhawa et al. (1979) and Mihara et al. (1980). $0.1 \mathrm{~mL}$ liver homogenate $(25 \%$ w/v) added with $0.1 \mathrm{~mL} 1 \mathrm{M}$ Tris- $\mathrm{HCl}(\mathrm{pH} 7), 0.1 \mathrm{~mL}$ $1.5 \mathrm{mM}$ ascorbic acid, $0.1 \mathrm{~mL} 4 \mathrm{mM}$ Fe-sulfate ammonium, and $0.1 \mathrm{~mL}$ distilled water in a total volume of $0.5 \mathrm{~mL}$. The mixture was incubated at $37^{\circ} \mathrm{C}$ for one $\mathrm{h}$ and then added with $0.5 \mathrm{~mL}$ Trichloroacetic Acid (TCA, 0.1\%) solution containing 1mM Butylated Hydroxytoluene (BHT) at $4^{\circ} \mathrm{C}$. The homogenate was added with $3 \mathrm{~mL}$ of $2 \%\left(\mathrm{vv}^{-1}\right)$ $\mathrm{H} 3 \mathrm{PO} 4$ solution and $1 \mathrm{~mL}$ of $0.6 \%\left(\mathrm{w} \mathrm{v}^{-1}\right) \mathrm{TBA}$ in a $20 \%$ TCA $\left(\mathrm{w} \mathrm{v}^{-1}\right)$. The mixture was incubated at $100^{\circ} \mathrm{C}$ for 30 min, then cooled to room temperature. After reaching room temperature, $4 \mathrm{~mL}$ of $100 \%\left(\mathrm{v} \mathrm{v}^{-1}\right) \mathrm{n}$-butanol was added to the mixture and then vortex vigorously. The butanol and the solution phases were separated by centrifugation at $3000 \mathrm{rpm}$ for $30 \mathrm{~min}$ (Labofuge 400R). The absorbance of the TBA-MDA complex in the butanol phase was measured with a spectrophotometer at $\lambda 532 \mathrm{~nm}$, while the non-specific absorbance value was measured at $\lambda 520 \mathrm{~nm}$. MDA concentration as the product of lipid peroxidation calculated by reducing the absorbance value at $\lambda 532 \mathrm{~nm}$ with the absorbance value at $\lambda 520 \mathrm{~nm}$.

The concentration of MDA was calculated using the following formula:

$$
[\mathrm{MDA}]=\frac{A}{\varepsilon \mathrm{xd}} \times V
$$

Where:

[MDA] : MDA concentration formed (nmol)

A : Different in absorbance value

$\mathcal{E}:$ MDA extinction coefficient $\left(155 \mathrm{mM}^{-1} \mathrm{~cm}^{-1}\right)$

d : Cuvette width $(\mathrm{cm})$

$\mathrm{v} \quad$ : Volume sample $(\mathrm{mL})$

\section{Superoxide dismutase (SOD) analysis}

Superoxide dismutase (SOD) was analyzed based on the method of Kubo et al. (2002) and Wijeratne et al. (2005) with slight modification. The method measures the activity of superoxide anion radicals produced enzymatically by the xanthine-xanthine oxidase system. A volume of $0.06 \mathrm{ml}$ liver homogenate was reacted with a solution consisted of $2.7 \mathrm{~mL}$ of $40 \mathrm{mM}$ Sodium Carbonate buffer containing $0.1 \mathrm{mM}$ EDTA ( $\mathrm{pH} \mathrm{10),} 0.06 \mathrm{~mL}$ of 10 $\mathrm{mM}$ Xantin, $0.03 \mathrm{~mL}$ of $0.5 \% \mathrm{BSA}$ and $0.03 \mathrm{~mL}$ of 2.5 $\mathrm{mM}$ NBT (nitroblue tetrazolium). Subsequently, the solution was added with $0.1 \mathrm{~mL}$ Xanthine Oxidase $(0.04$ units) and then incubated at room temperature for $30 \mathrm{~min}$. The absorbance was measured at $\lambda 560 \mathrm{~nm}$. The SOD activity (\%) was calculated using the following equation:

$$
\left[1-\frac{A}{B}\right] \times 100
$$

\section{Where:}

A: absorbance of sample solution;

B: absorbance of control

\section{Data analysis}

Data were analyzed using Analysis of Variance (ANOVA) at a confidence level of $95 \%$. If the treatments have a significant effect on the response, it was then followed by Duncan Multi Range Test (DMRT) with $\alpha=$ 0.05 .

\section{RESULTS AND DISCUSSION}

\section{LDso (Median Lethal Dose) value}

The preliminary study of acute toxicity test using a dose of $15 \mathrm{~g}$ extract $\mathrm{kg}^{-1} \mathrm{BW}$ was carried out to determine the $\mathrm{LD}_{50}$ of Selaginella extracts. The results showed that the mortality rate of three species of Selaginella extract reached $80 \%$ at the 24 hours after administering with Selaginella extracts, and the rest were still alive until the $7^{\text {th }}$ after administering Selaginella extract. The $\mathrm{LD}_{50}$ value could not be obtained from the preliminary study. On the last day of observation, showed that the bodyweight of mice received $S$. ornata and $S$. plana extracts were increased 1.1 and $0.5 \mathrm{~g}$, respectively, while mice received S. willdenowii extract experienced weight loss of $1.2 \mathrm{~g}$ (Figure 1).

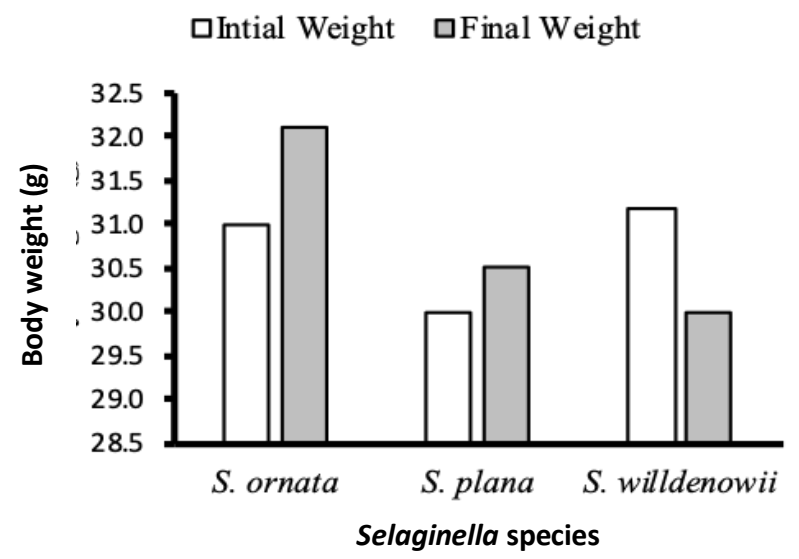

Figure 1. The initial and final body weight of mice received Selaginella extracts (S. ornata, S. plana, and $S$. willdenowii) in a

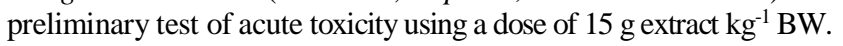


Table 1. Mortality rate (\%) of mice at $24 \mathrm{~h}$ after receiving Selaginella extract

\begin{tabular}{|c|c|c|c|c|}
\hline \multirow{3}{*}{ Species } & \multicolumn{4}{|c|}{ Doses (g extract kg ${ }^{-1}$ BW) } \\
\hline & 1 & 3 & 9 & 27 \\
\hline & \multicolumn{4}{|c|}{ Mortality (\%) } \\
\hline S. ornata & 0 & 0 & 50 & 100 \\
\hline S. plana & 0 & 0 & 100 & 100 \\
\hline S. willdenowii & 0 & 75 & 75 & 100 \\
\hline
\end{tabular}

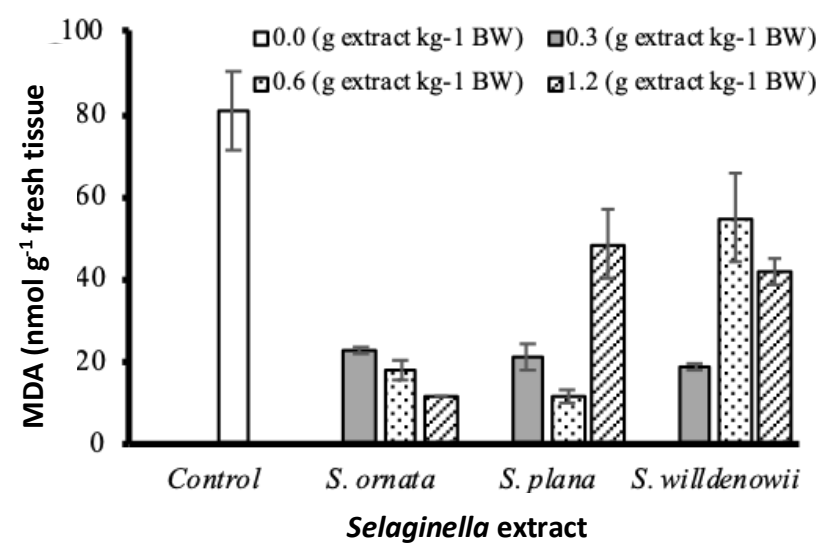

Figure 2. MDA concent of mice receiving an extract of $S$. ornata, $S$. plana, and $S$. willdenowii after being exposed to oxidative stress. The control treatment was a group of mice that did not receive Selaginella extracts but exposed to oxidative stress. Bars are standard errors of the mean

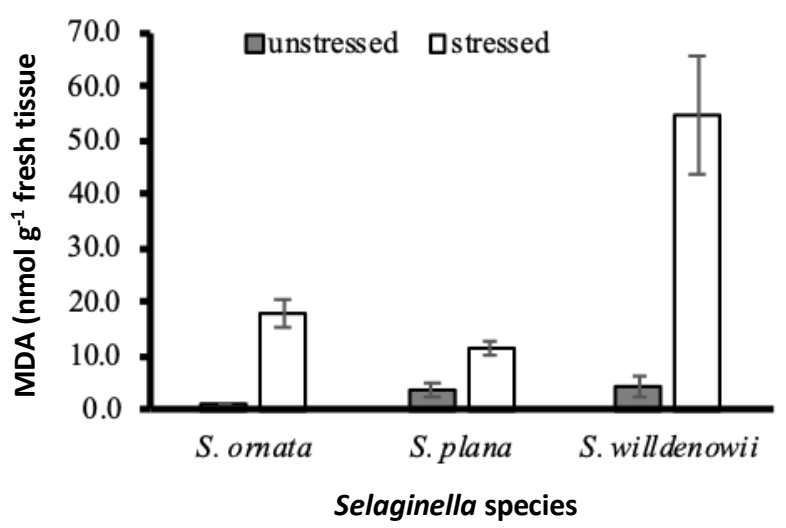

Figure 3. MDA concentration of stressed and unstressed mice receiving $0.6 \mathrm{~g}$ extract $\mathrm{kg}^{-1} \mathrm{BW}$ of three species of Selaginella extract. Unstressed mice were the mice that received the extract but not treated with oxidative stress. Bars are standard errors of the mean

Acute toxicity test to determine the $\mathrm{LD}_{50}$ value of the three Selaginella extracts was carried out in four different doses, i.e., 1, 3, 9, and $27 \mathrm{~g}$ extract $\mathrm{kg}^{-1} \mathrm{BW}$. The results showed changes in body weight on the $7^{\text {th }}$ after treatment.
In general, the mortality rates increased with increasing dose of Selaginella extract. The mortality rate of mice that received $S$. ornata and $S$. plana extracts increased in the treatment after receiving a dose of $\geq 9 \mathrm{~g}^{2}$ extract $\mathrm{kg}^{-1} \mathrm{BW}$, while the mortality rate of mice receiving $S$. willdenowii extract increased in the treatment of $\geq 3 \mathrm{~g}^{\text {extract } \mathrm{kg}^{-1} \mathrm{BW}}$ (Table 1). $\mathrm{LD}_{50}$ values of three species Selaginella extract was determined based on the percentage of mice mortality by Weil method (Weil 1952) were 9, 5.2, and $3 \mathrm{~g}$ extract $\mathrm{kg}^{-1}$ BW respectively for $S$. ornata, S. plana, and $S$. willdenowii extracts. Based on the $\mathrm{LD}_{50}$ and the differences with Median Effective Dose $\left(\mathrm{ED}_{50}\right)$, so that three doses of extract $\left(0.3,0.6\right.$, and $1.2 \mathrm{~g}$ extract kg $\left.^{-1} \mathrm{BW}\right)$ were applied to evaluate the antioxidant activity of three species of Selaginella extracts.

The effect of oxidative stress treatment on MDA content

Oxidative stress was applied to the starved mice with forced-swimming for five minutes a day. The effect of oxidative stress treatment in mice was measured as the content of MDA and SOD in stressed and unstressed mice. The results showed that the MDA concentration of liver in stressed mice $\left(80.65 \pm 9.68 \mathrm{nmol} \mathrm{g}^{-1}\right.$ fresh liver tissue) was higher than that of in unstressed mice $(\mathrm{MDA}=7.74 \pm 3.87$ nmol g-1 fresh liver tissue); while SOD content of stressed mice $(32.00 \pm 0.127 \%)$ was lower than that of unstressed $(52.60 \pm 0.48 \%)$. The results showed that stressed mice that were not administered with Selaginella extract had higher lipid peroxidation and lower protection to oxidative stress.

The results showed that species of Selaginella and the extract dose administration affected the level of lipid peroxidation as indicated by MDA concentration (Figure 2). An increasing dose of extract resulted in increased inhibition of lipid peroxidation as indicated by lowering MDA concentration in S. ornata administration. At a level of $1.2 \mathrm{~g}$, S. ornata extracts kg-1 BW reduced 8x of MDA content ((11.61 nmol g-1 fresh tissue) compared to negative control treatment. S. plana extract has a similar inhibitory effect on lipid peroxidation with that of $S$. ornata extract up to 8 times (11.61 nmol g-1 fresh tissue) at the dose of $0.6 \mathrm{~g}$ extract kg-1 $\mathrm{BW}$. However, the administration of $1.2 \mathrm{~g}$ extract kg-1 $^{-1} \mathrm{BW}$ results in increased MDA content (48.39 $\mathrm{nmol} \mathrm{g}^{-1}$ fresh tissue). The administration of $S$. willdenowii also reduced MDA content at the dose of $0.3 \mathrm{~g}$ extract $\mathrm{kg}^{-1} \mathrm{BW}$. Administration of $0.6 \mathrm{~g}$ extract kg-1 $\mathrm{BW}$ increased MDA content up to $54.84 \mathrm{nmol} \mathrm{g}^{-1}$ fresh tissue.

To evaluate the effect of Selaginella extract on lipid peroxidation of stressed and unstressed mice, a $0.6 \mathrm{~g}$ extract $\mathrm{kg}^{-1} \mathrm{BW}$ of each Selaginella species was administered to the stressed and unstressed mice. Figure 3 showed the MDA contents in unstressed mice were not significantly different despite receiving Selaginella extracts from different species. However, the administration of different species of Selaginella extracts affected MDA contents significantly. The results showed that administration of $S$. ornata and S.plana extracts were able to reduce MDA content significantly compared to that of $S$. willdenowii extract. 


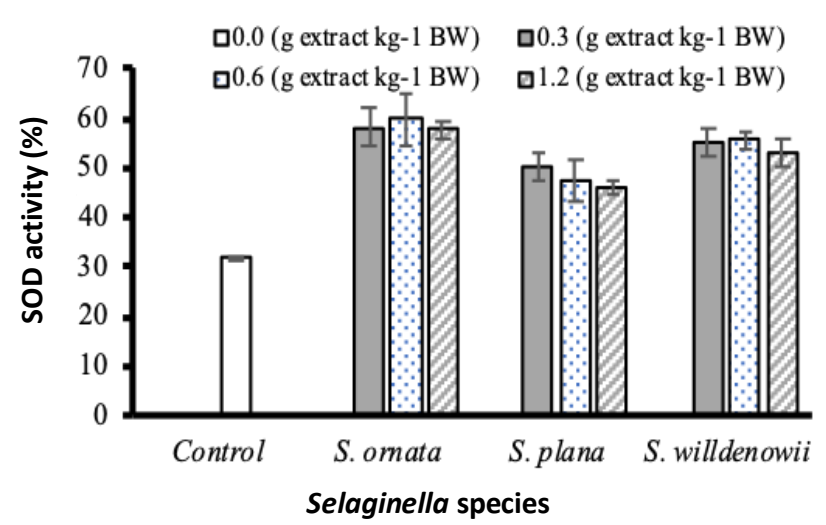

Figure 4. SOD activity (\%) of control and oxidative stressed mice treated with extract of $S$. ornata, S. plana, and S. willdenowii. Control was a group of mice that did not receive Selaginella extracts but exposed to oxidative stress. Bars are standard errors of the mean

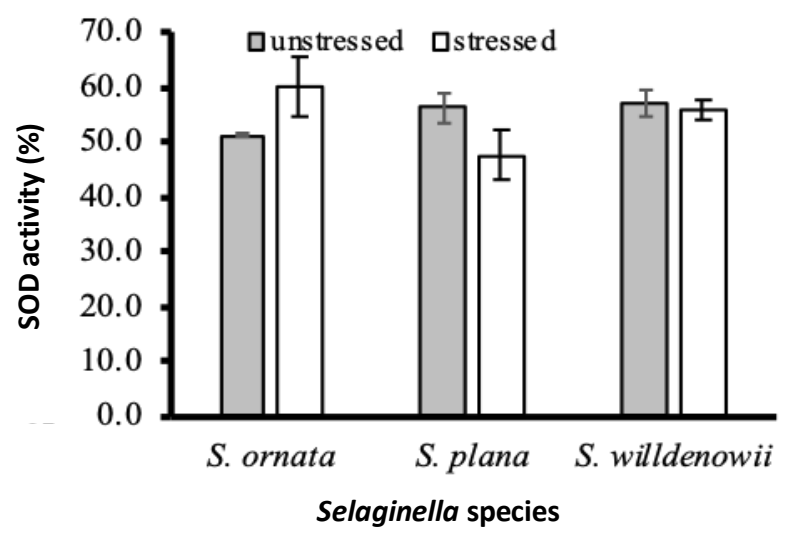

Figure 5. SOD activity of stressed and unstressed mice receiving $0.6 \mathrm{~g}$ extract $\mathrm{kg}^{-1} \mathrm{BW}$ of three species of Selaginella extract. Unstressed mice were the mice that received the extract but not treated with oxidative stress. Bars are standard errors of the mean

\section{Superoxide Dismutase (SOD) Activity}

Superoxide dismutase analysis used the xanthin-xanthin oxidase system that measured superoxide radicals produced by the reaction between xanthine and xanthine oxidase. Superoxide radicals oxidize yellow tetrazolium salts to form blue formazan. When there is an activity of SOD in the system, superoxide radicals will be neutralized, and as a consequence the higher SOD activity, the lower superoxide radicals, and less formazan formed.

The administration of different species of Selaginella extract in oxidatively stressed mice results in different effects on SOD activity. The average SOD activity of stressed mice treated with $0.3-1.2 \mathrm{~g}$ extract $\mathrm{kg}-1 \mathrm{BW}$ of S.ornata and S. willdenowii was $51.9 \%$ and $49.0 \%$, respectively which was higher compared to SOD activity in the mice treated with $S$. plana extract $(43.8 \%)$. It means that extract of S.ornata and S.willdenowii were potentially able to neutralize superoxide radicals better than that of $S$. plana (Figure 4). However, there were no significant differences in SOD activity among the doses of extract within the same Selaginella extract.

The SOD activity in stressed and unstressed mice responded differently to different Selaginella extract when $0.6 \mathrm{~g}^{2}$ extract $\mathrm{kg}^{-1} \mathrm{BW}$ applied (Figure 5). SOD activity was significantly increased in stressed mice compared to that of unstressed mice when $S$. ornata extract was administered. Conversely, the SOD activity declined in stressed mice when treated with $S$. plana extract. The level of SOD activity in mice treated with $S$. willdenowii extract was not significantly different between stressed and unstressed mice. It means $S$. ornata extract at concentration of $0.6 \mathrm{~g}$ $\mathrm{kg}^{-1} \mathrm{BW}$ could increase antioxidant activity in the stressed mice.

\section{Discussion}

Selaginella ornata, S. plana, and S. willdenowii have been used as herbal medicine to treat several diseases, especially in West Java community (Chikmawati et al. 2009). A scientific study on ethanol extract of Selaginella species could be useful to prove that the plant extract has potential benefits as antioxidant. A preliminary test to determine the level of toxicity based on the median lethal dose $\left(\mathrm{LD}_{50}\right)$ was crucial to be done before testing the extract on experimental animals. An acute toxicity test was performed to get information about the toxicity categories of substances being tested (Weil 1952; Harmita and Radji 2008). The results of the acute toxicity test showed that $S$. ornata and S. plana extracts were categorized as slightly toxic, while the $S$. willdenowii extract was categorized as quite toxic. The higher the $\mathrm{LD}_{50}$ value, the lower the toxicity. $S$. ornata extract has the highest $\mathrm{LD}_{50}$ value $(9 \mathrm{~g}$ extract $\mathrm{kg}^{-1} \mathrm{BW}$ ) compared to the other two extracts, so the $S$. ornata extract is less toxic and expected to be safer than the other two species of Selaginella.

The differences in toxic categories of three species of Selaginella may affect changes in body weight at the end of the experiment (Figure 1). The changes in the bodyweight of mice may be due to differences in the level of toxicity related to chemical compounds of each Selaginella extract that was administered at the same concentration. S. ornata and S. plana extracts categorized as slightly toxic were able to increase body weight of mice, while $S$. willdenowii extract categorized as quite toxic caused weight loss in mice. The toxicity level of plant extract is related to the secondary metabolites content of the extract (Hutapea 1999). The main secondary metabolite compound in Selaginella is biflavonoids (Seigler 1998). Previous phytochemical screening showed that ethanol extract of $S$. ornata, S. plana, and S. willdenowii from Java Island contain alkaloids, tannins, saponins, and steroids (Chikmawati et al. 2012). S. willdenowii was more toxic might be due to higher saponin content than that of $S$. ornata and S. plana. As it has been reported by Diwan et al. (2000), saponin in high concentration could be toxic for mice.

Evaluation of the antioxidant activity of Selaginella extract in mice was done by administering the extract before being treated with oxidative stress. The results showed that administration of Selaginella extract in mice 
with and without oxidative stress had a different effect on lipid peroxidation that indicated by different MDA concentrations. During stress conditions, the body needs energy-producing compounds. Physiologically, in conditions of food shortage, the body has to maintain blood glucose levels. Liver glycogen can only provide glucose for a few hours, and after that, the process of gluconeogenesis in the liver requires a substrate from other tissues that derived from glycogenic amino acids and fats (Montgomery et al. 1983). Neutral fat is catabolized to fatty acids and glycerol. Catabolism of fatty acids during normal conditions is different from catabolism during starvation conditions. Catabolism of fatty acids under normal conditions occurs in the mitochondria through $\beta$ oxidation processes. However, under starvation condition, there is an increase in the $\beta$-oxidation process in the peroxisomes (a minor pathway in the $\beta$-oxidation process). The increase of $\beta$-oxidation activity in the peroxisomes increases the number of free radicals (oxidants) which are metabolic byproducts (Orellana et al. 1992; Wresdiyati \& Makita 1995). It was reported that free radicals, such as reactive oxygen species (ROS), that were produced from biochemical processes in the body could increase lipid peroxidation of unsaturated lipids in cell membranes (Alfarabi et al. 2010). Lipids that contain unsaturated fatty acids are easily attacked by free radicals in their double bonds and form lipid peroxidation that causes structural damage. Free radicals attack subsequently results in the emergence of various diseases such as heart disease, atherosclerosis, stroke, and cancer (Hariyatmi 2004; Alfarabi et al. 2010).

Lipid peroxidation assay by measuring MDA concentration in biological materials has been widely used as an indicator of oxidative damages, especially the damage of unsaturated fat (Okhawa et al. 1979). The administration of $S$. ornata extract in mice caused the lowest lipid peroxidation compared to the two other Selaginella species. Under stress conditions, administration of $S$. ornata extracts with a dose of $0.6 \mathrm{~g}$ extract $\mathrm{kg}^{-1} \mathrm{BW}$ to mice was able to suppress lipid peroxidation level $14.4 \%$ lower than mice without the administration of Selaginella extract (Figure 2). The inhibitory activity of Selaginella extracts to lipid peroxidation in mice due to biflavonoid content. Biflavonoid has the potential as an antioxidant (Gayathri et al. 2005; Chikmawati et al. 2009). Biflavonoids have a series of hydroxyl donors $(\mathrm{OH})$, so they are capable of suppressing lipid peroxidation at the initiation step, inhibiting free radicals from developing new free radicals (Rahman et al. 2007). Flavonoid compounds of Selaginella extract may be able to protect cell membranes from free radical attack (Saija et al. 1995).

The administration of $S$. ornata, S. plana, and $S$. willdenowii extracts in mice reduced the level of lipid peroxidation to a relatively similar level at a dose of $0.3 \mathrm{~g}$ extract $\mathrm{kg}^{-1} \mathrm{BW}$. However, the administration of $S$. plana (1.2 $\mathrm{g}$ extract $\mathrm{kg}^{-1} \mathrm{BW}$ ) and $S$. willdenowii (0.6 and $1.2 \mathrm{~g}$ extract $\mathrm{kg}^{-1} \mathrm{BW}$ ) caused a higher increase in lipid peroxidation activity compared to that of $0.3 \mathrm{~g}$ extract $\mathrm{kg}^{-1}$ BW. The high increase in lipid peroxidation in both Selaginella extracts might be due to the toxic effects at high doses (Figure 2). The toxic effect of the extract might be due to other chemical compounds in the Selaginella extract, including saponins and alkaloids. Previous phytochemical tests by Chikmawati et al. (2012) showed that $S$. willdenowii extract contains more saponins than the other two Selaginella extracts. Nio (1989) reported that saponins have a bitter taste and strong toxic effects on fish and amphibians. Saponin was also showed toxic effects in mice on concentration basis. The higher concentration of saponin applied to mice, the higher toxicity as represented by higher percentage of mice mortality (Diwan et al. 2000). Other bioactive materials, such as alkaloids, are also suggested to have toxic effects (Zulak et al. 2006).

The administration of the Selaginella extract at a dose of $0.3 \mathrm{~g}$ extract $\mathrm{kg}^{-1} \mathrm{BW}$ has been shown to lower MDA concentration in all mice receiving Selaginella extracts (Figure 2). It means that the administration of $0.3 \mathrm{~g}$ extract $\mathrm{kg}^{-1} \mathrm{BW}$ is sufficient to inhibit lipid peroxidation. Results of this research showed that the administration of $S$. ornata and $S$. plana extracts at doses of 1.2 and $0.6 \mathrm{~g}_{\text {extract } \mathrm{kg}^{-1}}$ BW, was the best dose of each Selaginella because it was able to suppress MDA at the lowest levels (11.61 $\mathrm{nmol} \mathrm{g}^{-1}$ fresh tissue) (Figure 2).

MDA levels of mice without oxidative stress, but received Selaginella extracts were lower compared to mice without oxidative stress and without administration of Selaginella extract. It proves that Selaginella extract can suppress the level of lipid peroxidation not only in the stressed mice but also in the unstressed mice. Based on the results, it can be concluded that Selaginella extract has the potential as an antioxidant, and it can be used to overcome the adverse effects of oxidative stress.

Superoxide dismutase is an enzyme that participates in the process of degradation of intracellular free radical compounds, such as superoxide anions, hydrogen peroxide, and oxygen radical. The enzyme inhibits the simultaneous presence of superoxide and hydrogen peroxide anions derived from the formation of hydroxyl radicals (Wresdiyati et al. 2007). The administration of S. ornata extract $\left(0.3 \mathrm{~g}\right.$ extract $\left.\mathrm{kg}^{-1} \mathrm{BW}\right)$ to mice showed the highest antioxidant activity indicated by $51.9 \%$ of SOD activity which was $20 \%$ higher than the SOD activity in negative control mice (32\%). The increasing SOD activity due to the administration of Selaginella extract can inhibit the production of superoxide ions $\left(\mathrm{O}_{2}^{-}\right)$and peroxynitrite (ONOO-) (Menvielle-Bourg 2005).

High antioxidant activity is indicated from the inhibition of lipid peroxidation (low MDA concentration) and increased SOD activity. SOD enzymes are a group of protective enzymes that function as a defense system capable of protecting cells from the influence of oxygen metabolites (Hariyatmi 2004). Consumption of antioxidants originated from plants can increase the resistance to oxidative stress (Sanchez-Moreno et al. 1999). Selaginella was reported to contain bioactive compounds so that Selaginella has a potential source of active ingredients (secondary metabolites), especially biflavonoids. Amentoflavone biflavonoid has been detected in specific Selaginella extract, including $S$. willdenowii extract $(2.46$ ppm), but it was not detected in $S$. ornata and $S$. plana. 
Other types of biflavonoids, such as robustaflavone may be present in both Selaginella species (Chikmawati et al. 2012). Yang et al. (2006) reported that amentoflavone in $S$. tamariscina could inhibit the production of NO (nitric oxide) in macrophages through inactivation of nuclear factor $-\kappa \mathrm{B}(\mathrm{NF}-\kappa \mathrm{B})$, but it is not for robustaflavone. Wang et al. (2015) reported that $S$. doederleinii contains nine biflavone compounds that are potential as antioxidants. Biflavones were divided into three types, i.e., amentoflavone-type, robustaflavone-type, and hinokiflavone-type.

Testing of antioxidant activity by measuring MDA and SOD levels of mice liver homogenate showed differences among the three Selaginella species. The method to evaluate the antioxidant activity of Selaginella extract using lipid peroxidation analysis seems to be more sensitive than using SOD analysis. The lipid peroxidation data tells more about the ability of Selaginella extract to overcome oxidative stress due to all types of ROS than the SOD data does. The results showed that Selaginella extract had the potential to be further developed into standardized herbs and phytopharmaca.

\section{In conclusion}

, the extract of S. ornata, S. plana, and S. willdenowii have different antioxidant activities. $S$. ornata has the highest antioxidant activity with the lowest MDA concentration (11.61 nmol g-1 fresh tissue) and the highest average of SOD activity (51.9\%). An extract dose of $0.3 \mathrm{~g}$ kg-1 BW of Selaginella extract was sufficient to suppress lipid peroxidation as low as 23.2 to $28 \%$ and increase SOD activity up to $54.6 \%$. Testing the antioxidant activity of Selaginella extract using lipid peroxidation analysis yields better results than using SOD analysis.

The median lethal dose $\left(\mathrm{LD}_{50}\right)$ of $S$. ornata and S. plana extract were categorized as slightly toxic ( 9 and $5.2 \mathrm{~g}$ extract $\left.\mathrm{kg}^{-1} \mathrm{BW}\right)$, whereas $S$. willdenowii extract was categorized quite toxic ( $3 \mathrm{~g}$ extract $\mathrm{kg}^{-1} \mathrm{BW}$ ). Among the three Selaginella species, $S$. ornata extract is less toxic than other extracts. Selaginella extract had the potential to be further developed into standardized herbs and phytopharmaca.

\section{ACKNOWLEDGEMENTS}

The authors extend their appreciation to the Basic Science Grant funded by Directorate General of Higher Education, Indonesian Ministry of Education granted to Dr. Tatik Chikmawati.

\section{REFERENCES}

Alfarabi M, Bintang M, Suryani, Safithri M. 2010. The comparative ability of antioxidant activity of Piper crocatum in inhibiting fatty acid oxidation and free radical scavenging. Hayati J Biosci 17: 201204. [Indonesian]

Chai TT, Wong FC. 2012. Antioxidant properties of aqueous extracts of Selaginella willdenowii. J Med Plants Res 6: 1289-1296.
Chikmawati T, Wijayanto A, Miftahudin. 2009. The potential of Selaginella as antioxidant. Seminar Nasional Biologi XX, Universitas Islam Negeri Malang, Malang, 25 Juli 2009. [Indonesian]

Chikmawati T, Setyawan AD, Miftahudin. 2012. Phytochemical composition of Selaginella spp. from Java Island Indonesia. Makara J Sci 16: 129-133. [Indonesian]

Dawidowicz AL, Wianowska D, Baraniak B. 2006. The antioxidant properties of alcoholic extracts from Sambucus nigra L. (antioxidant properties of extracts). LWT-Food Sci Technol 39: 308-315.

de Oliveira Macêdo LAR, de Oliveira Júnior RG, Souza GR, de Oliveira AP, de Lavor EM, e Silva MG, Pacheco AGM, de Menezes IRA, Coutinho HDM, do Ó Pessoa C, da Costa MP, da Silva Almeida JRG. 2018. Chemical composition, antioxidant and antibacterial activities and evaluation of cytotoxicity of the fractions obtained from Selaginella convoluta (Arn.) Spring (Selaginellaceae). Biotechnol Biotechnological Equipment 32: 506-512.

Diwan FH, Abdel-Hassa IA, Mohammed ST. 2000. Effect of saponin on mortality and histopathological changes in mice. E Mediterr Health $\mathrm{J}$ 6: 345-351

Garg NK, Khatri P, Gupta S. 2012. Memory enhancing activity of methanolic extract of Selaginella bryopteris in Swiss Albino Mice. Pharmatutor. www.pharmatutor.org.

Gayathri V, Asha V, Subromanian A. 2005. Preliminary studies on the immunomodulatory and antioxidant properties of Selaginella species. Indian J Pharmacol 37: 381-385.

Ghasemzadeh A, Omidvar V, Jaafar HZE. 2012. Polyphenolic content and their antioxidant activity in leaf extract of sweet potato (Ipomoea batatas). J Med Plants Res 6: 2971-2976.

Hariyatmi. 2004. The ability of Vitamin E as an antioxidant against free radicals in the elderly. MIPA Journal Surakarta. UMS 14(1). [Indonesian]

Harmita, Radji M. 2008. Analisis Hayati. Penerbit Buku Kedokteran EGC, Jakarta. [Indonesian]

Hasani P, Yasa N, Vosough-Ghanbari S, Mohammadirad A, Dehghan G, Abdollahi M. 2007. In vivo antioxidant potential of Teucrium polium, as compared to $\alpha$-tocopherol. Acta Pharm 57: 123-129.

Hutapea JR. 1999. Inventaris Tanaman Obat Indonesia. Jilid V. Badan Penelitian dan Pengembangan Kesehatan, Departemen Kesehatan, Jakarta. [Indonesian]

Irudayaraj V, Janaky M, Johnson M, Selvan N. 2010. Preliminary phytochemical and antimicrobial studies on a spike-moss Selaginella inaequalifolia (Hook. \& Grev.) Spring. Asian Pac J Trop Med 3: 957960.

Kubo I, Masuoka N, Xiao P, Haraguchi H. 2002. Antioxidant activity of dodecyl gallate. J Agric Food Chem 50: 3533-3539.

Kumar A, Kaur R, Arora S. 2010. Free radical scavenging potential of some Indian medicinal plants. J Med Plants Res 4: 2034-2042.

Mavundza EJ, Tshikalange TE, Lall N, Hussein AA, Mudau FN, Meyer JJM. 2010. Antioxidant activity and cytotoxicity effect of flavonoids isolated from Athrixia phylicoides. J Med Plant Res 4: 2584-2587.

Menvielle-Bourg FJ. 2005. Superoxide dismutase (SOD), a powerful antioxidant, is now available orally. Phytothérapie 3: 1-4

Mihara M, Uchiyama M, Fukazawa K. 1980. Thiobarbituric acid value on fresh homogenate of rat as parameter of lipid peroxidation in aging, $\mathrm{CCl}_{4}$ intoxication and vitamin e deficiency. Biochem Med 23: 302311.

Montgomery R, Dryer RL, Conway TW, Spector AA. 1983. Biokimia: Suatu Pendekatan Berorientasi Kasus-Kasus Jilid 1. Diterjemahkan Ismadi M. Penerbit Gajah Mada University Press, Yogyakarta. [Indonesian]

Mukhopadhyay R. 2001. A review of work on the genus Selaginella P. Beauv. Indian Fern J 18: 44-54.

Nimse SB, Pal D. 2015. Free radicals, natural antioxidants, and their reaction mechanisms. RSC Adv 5: 27986-28006

Nio KO. 1989. Zat-zat toksik yang secara alamiah ada pada bahan makanan nabati. J Cermin Dunia Kedokteran 58: 24-28. [Indonesian]

Okhawa H, Ohishi N, Yagi K. 1979. Assay for lipid peroxides in animal tissues by thiobarbituric acid reaction. Anal Biochem 95: 351-358.

Orellana M, Fuentes O, Rosenbluth H, Lara M, Valdes F. 1992. Modulatios of rats liver peroxisomal and microsomal fatty acids oxidation by starvation. FEBS 310: 193-196.

Rahman M, Riaz M, Desai UR. 2007. Synthesis of biologically relevant biflavonoids [Review]. Chem Biodivers 4: 2495-2527.

Sah NK, Singh SNP, Sahdev S, Banerji S, Jha V, Khan Z, Hasnain SE. 2005. Indian herb 'Sanjeevani' (Selaginella bryopteris) can promote 
growth and protect against heat shock and apoptotic activities of ultraviolet and oxidative stress. J Biosci 30, 499-505.

Saija A, Scalese M, Lanza M, Marzullo D, Bonina F, Castelli F. 1995. Flavonoids as antioxidant agents: importance of their interaction with biomembranes. Free Radic Biol Med 19: 481-486.

Sanchez-Moreno C, Larrauri JA, Saura-Calixto F. 1999. Free radical scavenging capacity an inhibition of lipid oxidation of wines, grape juices and related polyphenolic constituents. Food Res Int 32: 407412.

Seigler DS. 1998. Plant Secondary Metabolism. Kluwer, Dodrecht.

Sivaraman A, Johnson M, Parimelazhagan T, Irudayaraj V. 2013. Evaluation of antioxidant potential of ethanolic extracts of selected species of Selaginella. Indian J Nat Prod Res 4: 238-244.

Syaefudin, Juniarti A, Rosiyana L, Setyani A, Khodijah S. 2016. Nanoparticles of Selaginella doederleinii leaf extract inhibit human lung cancer cells A549. IOP Conf Ser.: Earth Environ Sci 31 (2016) 012029. DOI: $10.1088 / 1755-1315 / 31 / 1 / 012029$.

Wang G, Yao S, Zhang X, Song H. 2015. Rapid screening and structural characterization of antioxidants from the extract of Selaginella doederleinii Hieron with DPPH-UPLC-Q-TOF/MS method. Int J Anal Chem. DOI: 10.1155/ 2015/849769.

Weil CS. 1952. Tables for convenient calculation of median effective dose $\left(\mathrm{LD}_{50}\right.$ or $\left.\mathrm{ED}_{50}\right)$ and instructions for their use. Biometric 8: 249-263.
Wijeratne SSK, Cuppett SL, Schlegel V. 2005. Hydrogen peroxideinduced oxidative stress damage and antioxidant enzyme response in caco-2 human colon cells. J Agric Food Chem 53: 8768-8774.

Woo ER, Lee JY, Cho IJ, Kim SG, Kang KW. 2005. Amentoflavone inhibits the induction of nitric oxide synthase by inhibiting NF-kappa $\mathrm{B}$ activation in macrophages. Pharmacol Res 51: 539-546.

Wresdiyati T, Astawan M, Fithriani D, Adnyane IKM, Novelina S, Aryani S. 2007. Pengaruh $\alpha$-tokoferol terhadap profil superoksida dismutase dan malondialdehida pada jaringan hati tikus di bawah kondisi stres. J Veteriner 8: 202-209. [Indonesian]

Wresdiyati T, Makita T. 1995. Remarkable increase of peroxisomes in the renal tubule cells of Japanese monkeys under fasting stress. Pathophysiol 2: 177-182.

Yang JW, Pokharel YR, Kim MR, Woo ER, Choi HK, Kang KW. 2006. Inhibition of inducible nitric oxide synthase by sumaflavone isolated from Selaginella tamariscina. J Ethnopharmacol 105: 107-113.

Yao H, Chen B, Zhang Y, Ou H, Li Y, Li S, Shi P, Lin X. 2017. Analysis of the total biflavonoids extracts from Selaginella doederleinii by HPLC-QTOF-MS and its in vitro and in vivo anticancer effects. Molecules 22: 325-341.

Zulak KG, Liscombe DK, Ashihara H, Facchini PJ. 2006. Alkaloids. In: Crozier A, Clifford MN, Ashihara H (eds) 2006. Plant Secondary Metabolites: Occurrence, Structure, and Role in the Human Diet. Wiley-Blackwell Publ, New Jersey. 